\title{
The Construction Technology of Preschool Institutions: Eco-Friendly and Fire-Resistant Materials
}

\author{
Irina Salakhovna Ulbieva ${ }^{1}$, Karhan Mochkievich Uzhakhov ${ }^{1}$, Aminat Huseynovna Tsechoeva ${ }^{1}$, Aishat \\ Ruslanovna Dzangieva ${ }^{1}$, Magomed Karhanovich Uzhakhov ${ }^{2}$ \\ ${ }^{1}$ Ingush State University, Magas, Republic of Ingushetia \\ ${ }^{2}$ Lomonosov Moscow State University, Moscow, Russia
}

\begin{abstract}
Finishing work in construction is a type of construction and installation work that is performed at the final stage of construction and gives buildings a beautiful aesthetic appearance, creates the comfort of the interior and, most importantly, protects building structures against harmful atmospheric influences, corrosion, aging, and destruction.

The purpose of the study is to justify the use of eco-friendly and fire-resistant finishing materials in the construction of preschool institutions.

The study analyzed the requirements of SanPiN for finishing materials, as well as the main building materials used for interior and exterior decoration of buildings, namely, ceiling finishing, floor finishing, facade insulation, and roofing when constructing preschool educational institutions and general educational institutions safe in terms of ecological compatibility and fire safety.

Based on the conformity analysis of materials used for indoor and outdoor decoration of buildings with existing statutory acts and SanPiN requirements to the finishing materials used in preschool institutions, recommendations were given on the use of construction materials for finishing ceilings and floors, facade insulation and roof covering of preschool institutions.
\end{abstract}

Key words: fire-resistance rating of buildings, class of structural fire hazard of buildings, fire resistance limits and fire hazard classes of building structures.

\section{INTRODUCTION}

Finishing works cover a large number of individual technological processes and require special materials. For finishing works to be performed with high quality, it is necessary to use both traditional and contemporary effective materials. Finishing coats must meet both operational requirements, i.e. be resistant to mechanical stress, allow for sanitary and hygienic treatment, do not leave traces on objects when contacting them, keep a neat appearance during the expected useful life, and the requirements for environmental and fire safety [1-3].
In this regard, during the construction, reconstruction, and major repairs of children's institutions, special attention should be paid to the use of environmentally friendly and safe materials that ensure the health of children of preschool and school-age. It is during this period that the human immune system is formed, which largely determines the success of a person in later life [4].

At the same time, special importance is attached to the creation of an eco-friendly living environment in a preschool institution, where the child spends most of the time. In such conditions, the body is exposed to a large number of chemicals that migrate from building structures.

No less, if not more, importance is attached to the fire safety of construction materials since it affects not only the child's health but also life. Examples of fires that spread through the finishing systems of building facades indicate that they may be particularly dangerous. This danger is directly related to the design of the thermal insulation system and the type of thermal insulation material [5]. Thus, a fire in a 24-storied Grenfell Tower residential building in London on June 14, 2017, was one of the largest in terms of the number of dead and injured people. The fire started in one of the apartments on the lower floors due to a fire outbreak in the refrigerator, but through the poor-quality facing slabs of the building, the fire quickly engulfed almost the entire building. As a result, 80 people were killed and 68 received injuries of varying severity. Thermal insulation of the building was made of facing facade materials, namely, Reynobond PE composite panels. On January 8, 2018, a fire occurred in a 9-storied residential building in Tyumen. During the overhaul of the house, contractors used cheap flammable facing panels of the G4 flammability group. The flames covered about $1,500 \mathrm{~m} 2$ of the building envelope and part of the roof in a matter of minutes. As a result of the fire, the building was almost completely burned out from the outside.

The problems related to fire safety of finishing materials, including hinged ventilated ones, were studied by many researchers, both domestic and foreign.

In [6], L.V. Dobrogorskaya performed a study of the fire hazard of external walls with facade insulation. The authors believe that the regulatory requirements for facade insulation systems and methods for determining the fire hazard 
properties of such systems do not fully ensure the fire safety of buildings while in operation.

The unsolved problems of ensuring fire safety of structural solutions and the lagging of fire safety standards from contemporary architectural and design solutions are substantiated in the [7]. In [8], C.W. Leung and W.K. Chow consider European and American standards for testing finishing materials concerning fire propagation. In [9], E.A. Meshalkin analyzed publications related to the fire hazard of facade systems. The main elements of contemporary hinged facade systems were considered and the core measures to ensure the fire safety of these systems were proposed. The results of the spread of the flame over the surface of various finishing materials are demonstrated in [10].

However, in the authors' opinion, studies substantiating the use of finishing materials in the construction of preschool institutions in terms of environmental and fire safety are insufficient that stipulated the relevance of the present study.

\section{METHODS}

Research methods include general theoretical scientific methods, such as:

- the comparative analysis used to compare existing finishing materials in terms of degrees of environmental and fire safety; - the functional analysis used to determine the compliance of finishing materials with statutory acts of the SanPiN requirements.

\section{RESULTS}

The list of materials that meet environmental standards is compiled by the State Committee for Sanitary and Epidemiological Supervision, but, as practice shows, developers are not always guided by this list in their choice. According to experts, about $50 \%$ of all finishing materials on the market do not meet sanitary requirements.

This category includes many polymer materials that became widespread in the second half of the last century. Today, polymers are used for finishing walls and floors, as sound insulation materials, etc. Among polymers, the isocyanates, including some types of mounting foam are the most toxic since they emit hazardous substances when heated. When choosing polymer materials, construction companies should follow the provisions of SanPiN 2.1.2.729-99 [11], which establish sanitary and hygienic requirements and regulate the scope of polymer application. Also, it is necessary to make sure that compliance with the standards is confirmed by the sanitary and epidemiological inspection report.

Below are considered the requirements of SanPiN for finishing materials used when constructing preschool institutions.

Construction materials with high radioactivity may pose a certain risk. As a rule, raw materials for their production are natural materials that contain micro admixtures of uranium, radium, thorium, and potassium isotopes. Many minerals are characterized by increased radioactivity, for example, granite and quartz diorite, as well as sedimentary clays. For this reason, all materials that contain natural minerals must be provided with a radioactivity inspection report. It should be remembered that the concentration of radioactive elements in construction materials obtained using such raw materials is small, and measurements with a conventional dosimeter rarely show the actual level of radiation exceeding the natural radiation background.

The main threat to the body is associated with radon, which liberates during the decay of radionuclides. Its daughter products can condense and precipitate on the smallest aerosol particles, making them radioactive. Settling on the surface of the upper respiratory tract, the particles create sources of alpha irradiation of cells that cause cancer development.

Thus, for the construction and decoration of buildings, it is necessary to choose materials with low content of natural radionuclides, whose radiation complies with the radiation safety standards (NRB-99) [12] and the requirements of GOST 30108-94 Construction materials and products: Determination of the specific effective activity of natural radionuclides [12].

The item 5.1 of the Resolution of the Chief state sanitary physician of the Russian Federation of July 22, 2010, No. 91 "On the approval of SanPiN 2.4.1.2660-10 "Sanitary and epidemiological requirements for the arrangement, content, and organization of the work pattern in preschool organizations" [13] states that all construction and finishing materials must be harmless to children's health.

\section{RESULTS AND DISCUSSION}

Ceiling finishing According to the item 5.4. of the SanPiN [13], for finishing ceilings in premises with normal operating mode, it is necessary to use chalk or lime whitewash. It is allowed using also water-based paint.

Contrary to this requirement, Armstrong suspended ceilings and other synthetic materials are used quite often.

The Ministry of Emergency Situations of Russia has banned the use of Armstrong slag-wool ceiling when constructing children's educational institutions. Commenting this restriction, one should note again that materials that are allowed to be used in various premises are indicated in Federal Law No. 123 Technical regulations on fire safety requirements (article 134, Table 28) [14].

In sleeping rooms and wards, as well as in the building premises of preschool educational organizations of F1.1 subclass it is not allowed using decorative finishing materials and floor coverings with fire hazard higher than class KM2. Thus, one can boldly assert that standard suspended Armstrong ceilings of KM1 class can be used in preschool and children's educational institutions. However, this does 
Irina Salakhovna Ulbieva et al., International Journal of Emerging Trends in Engineering Research, 8(4), April 2020, 1227 - 1231

not apply to evacuation zones, staircases, and lobbies, where materials of KM0 (NG) class must be used regardless of the type of building.

Floor finishing. In item 5.5 of the SanPiN [13], a requirement is made concerning the used floors.

Floors in group premises located on the first floor should be made insulated and/or heated, with a controlled temperature regime on the floor surface. In the main premises, wood should be used as floor material (plank floors that are covered with oil paint or parquet). It is allowed covering floors with synthetic polymer materials that are harmless to children's health and allow for wet treatment and disinfection.

For example, using Marmoleum which is natural material based linoleum is ideal for preschool institutions, since it contains only natural ingredients, namely:

- cork crumbs and wood flour which provide the necessary elasticity and softness of this floor covering;

- jute fiber which gives it good resistance to longitudinal deformations;

- lime component and glue base made of linseed oil serve for the strength of the material.

Such coating is completely eco-friendly, noise-absorbing, and at the same time has a low thermal conductivity coefficient. The material is water-repellent and easy to clean with detergents.

The facade insulation. General requirements for fire safety of facade insulation are established by the Technical regulations on fire safety requirements [14]. They refer to the need to prioritize the implementation of fire prevention measures provided for by the project, which was developed following current standards. Despite this, explicit requirements for fire safety of facade systems did not exist for a long time.

When facade insulation technologies first appeared on the Russian market, it was difficult to determine the fire hazard of a particular system and recommend it for use in buildings of various functional purposes due to the imperfection of the regulatory framework. The current standards allow doing this. Based on the Technical regulations and GOST Standards, it is possible to comprehensively assess the fire safety of a particular facade system, as well as the hazard of materials used in its construction.

Fire safety of facade systems is regulated by GOST 31251-2003 [15].

Even more serious requirements are applied to thermal insulation in the design of hinged ventilated facade systems. This is because the gap between the thermal insulation layer and the decorative screen is designed to ensure upward airflow. When using flammable thermal insulation, a fire can spread across the facade of a building in a very few minutes. Therefore, when installing ventilated façade systems, specialists of the Central Research Institute of Building Structures named after V.A. Kucherenko recommend using nonflammable thermal insulation based on stone wool whose fibers can withstand temperatures up to $1,000^{\circ} \mathrm{C}$. Thus, the material serves a barrier to fire, preventing its spread. Thermal insulation made of stone wool can be used without restrictions in the number of stories of the building.

There are several documents, namely, GOSTs, according to which the basic indicators of products made of slag-wool are regulated:

- GOST 9573-96 Thermal insulation slabs made of mineral wool on a synthetic binder [16];

- GOST 22950-95 Rigid mineral wool slabs on a synthetic binder: Specifications [17].

Currently, most manufacturers produce slag-wool according to the requirements of GOST, as well as in-house Specifications (TU), which prescribe much higher requirements for the insulation produced than those listed in GOST.

The use of stone wool as insulation has become widespread because this natural material (approximately for 95\% consisting of stone) is nonflammable and durable. Stone wool received the main application as insulation for building envelope structures (facades and roofs). Due to its thermal insulation properties, the material allows preventing heat loss through the surface in the cold season and keeping the premises cool during the warm season. Currently, stone wool is widely used for the following structures:

- walls: in ventilated facade systems, facades with a thin or thick plaster layer, and light external frame structures;

- interior partitions: inside the premises as acoustic isolation;

- floors: for thermal and/or acoustic isolation laid on floor joists or slabs, with the possibility of providing screeds;

- roofs (pitched, flat): it is possible to lay thermal insulation on flat roofs on reinforced concrete slabs or profiled flooring; - thermal insulation of equipment and pipelines: due to the noncombustibility and high melting point of the fibers, stone wool can be used to insulate surfaces with temperatures up to $700^{\circ} \mathrm{C}$.

In recent years, after a series of fires in high-rise buildings, the attention of experts has been drawn to the issues of fire safety of aluminum composite panels (ACP), which are most often used in the lining of ventilated facade systems. In an attempt to save money, builders often prefer inexpensive ACPs with a polyethylene-based binder layer. All composite panels of this type belong to the G4 group of combustibility: the flame development occurs at a temperature of $120^{\circ} \mathrm{C}$, while the combustion products contain toxic compounds. It is prohibited to use such panels in the construction of child welfare institutions.

When choosing composite panels, one cannot rely on the results of tests according to GOST 30244-94 [18] and GOST 30402-96 [19]. Only full-scale fire tests following GOST 31251-2008 [15] give an idea of the actual fire danger. Despite this, only a small part of the ACPs from among the 
Irina Salakhovna Ulbieva et al., International Journal of Emerging Trends in Engineering Research, 8(4), April 2020, 1227 - 1231

products available on the Russian market has passed this test. Therefore, the choice of composite panels can be guided by the European classification of fire safety. According to this classification, all building materials are divided into seven main classes: A1, A2, B, C, D, E, and F.

So, class A1 is assigned to the materials that have received the best test results. This corresponds to the NG group. Class A2 is the analog of the group G1, while class E is the supposed analog of G4. All nonclassified materials are attributed to class F. Almost all composite panels entering the Russian market have a certain class of fire hazard according to the European classification.

In most facade systems that have successfully passed tests according to GOST 31251 [15], fire-prevention boxes were installed along the perimeter of the interface between the product and window openings. Framing the window openings, they protrude above the surface of the exterior facade cladding and serve to change the trajectory of the flame torch escaping from the window opening. This construction solution allows reducing the heating of the composite panels to prevent the melting and ignition of the middle polymer layer.

Porcelain stoneware tiles are another common type of cladding. Although these tiles belong to the NG group, they are dangerous because they crack when heated, resulting in a partial collapse of the facade.

For hinged facade systems with a frame made of aluminum alloys, it is necessary to provide a design in which the porcelain stoneware tiles would remain in their places even if partially destroyed. This can be done, for example, by increasing the number of special fastening elements (clips), whose design should allow holding parts of the tile. Also, among more than 150 types of porcelain stoneware presented on the building materials market, only eight types have passed fire tests for application in facade systems.

In terms of fire safety, the best material for facing buildings is lining brick, which has good thermal properties.

Roof covering. A lot of questions arise from designers on the issue of determining the structural fire hazard of roofing. When determining the fire hazard, the question arises, whether to consider the entire roofing pie as a single whole or each of its constituent elements. Designers do not have a common standpoint on this issue. The regulations (FZ-123, Tables 21 and 22) [14] do not give clear understanding of this issue. In order not to prove the legality of the chosen materials at the stage of state construction expertise, only noncombustible materials should be included in the roofing pie.

Regulatory documents lag behind rapidly developing technologies for the production of construction materials. It is necessary to develop standard components within the framework of the state program that would allow designers to clearly understand the possibility of using certain materials in roofing or facade decoration.

\section{CONCLUSION}

The research results have shown that in preschool and children's educational institutions, standard suspended Armstrong ceilings of the KM1 class can be used. However, materials of class $\mathrm{K} 0(\mathrm{NG})$ must be used in evacuation zones, stairwells, and lobbies.

Marmoleum, i.e. linoleum based on natural materials, is an ideal material for use as a floor covering in preschool institutions. Lining brick having good thermal properties is the best material for facing buildings in terms of fire safety.

\section{REFERENCES}

1. E.S. Kuchenin, I.O. Loshkarev, N.V. Lutovinova, M.S. Lavrentieva. Environmental Law: International Trends and National Characteristics. Journal of Environmental Management and Tourism, 10(7), pp. 1458-1465, 2020.

2. M.R. Kudrin, O.A. Krasnova, A.G. Koshchaev, O.V. Koshchaeva, M.B. Ulimbashe, N.V. Konik, S.V. Shabunin. Biological Processing of Renewable Raw Materials Resources with Regard to the Environmental and Technological Criteria. Journal of Ecological Engineering, 20(11), pp. 58-66, 2019. https://doi.org/10.12911/22998993/113192

3. M.A. Aitkazina, E. Nurmaganbet, S. Syrlybekkyzy, S. Koibakova, A.E. Zhidebayeva, M.Zh. Aubakirov. Threats to Sustainable Development Due to Increase of Greenhouse Gas Emissions in A Key Sector. Journal of Security and Sustainability Issues, 9(1), pp. 227-240, 2019.

https://doi.org/10.9770/jssi.2019.9.1(17)

4. A. Novoselov, I. Novoselova, R. Aliev, A. Avramenk. Preventing Regional Social and Environmental Conflicts During Oil Pipeline Construction Projects. Entrepreneurship and Sustainability Issues, 7(1), 773-785, 2019.

https://doi.org/10.9770/jesi.2019.7.1(55)

5. A.Ya. Korolchenko. Pozharnaya opasnost' stroitel'nyh materialov: Uchebnoe posobie [Fire hazard of construction materials: Textbook]. Moscow: Pozhnauka, p. 232, 2005.

6. L.V. Dobrogorskaya. Mery predotvrashcheniya pozharov navesnyh ventiliruemyh fasadov [Measures to prevent fires of hinged ventilated facades]. Construction of unique buildings and structures, 16, pp. 34-51, 2016.

7. L.A. Ginzberg, P.I. Barsukova. Pozharnaya bezopasnost' konstruktivnyh reshenij proektiruemyh i rekonstruiruemyh zdanij [Fire safety of structural solutions for designed and reconstructed buildings]. Yekaterinburg: Ural University Press, p. 54, 2015.

8. C.W. Leung, W.K. Chow. Review of four standard tests on flame spreading. International Journal on Engineering Performance-Based Fire Codes, 3(2), pp.67-86, 2001. 
9. E.A. Meshalkin. Fasadnye sistemy: tendencii primeneniya i pozharnaya opasnost' [Facade systems: Application trends and fire hazard]. Fire and Explosion Safety, 16(2), pp. 12-18, 2007.

10. I.I. Rudchenko, A.V. Bychkov, G.V. Serga, D.K. Levchenko. Materialy i konstrukcii zdanij $\mathbf{v}$ usloviyah pozhara [Materials and structures of buildings under fire conditions]. Krasnodar: Kuban State Agrarian University, p. 220, 2019.

11. SanPiN 2.1.2.729-99. Polimernye i polimersoderzhashchie stroitel'nye materialy, izdeliya i konstrukcii. Gigienicheskie trebovaniya bezopasnosti. [Polymer and polymer-containing construction materials, products and structures. Hygienic safety requirements].

12. GOST 30108-94. Materialy i izdeliya stroitel'nye. Opredelenie udel'noj effektivnoj aktivnosti estestvennyh radionuklidov (s Izmeneniyami $N$ 1, 2) [Construction materials and products. Determination of the specific effective activity of natural radionuclides (with Amendments No. 1, 2)].

13. SanPiN 2.4.1.2660-10. Sanitarno-epidemiologicheskie trebovaniya $\mathrm{k}$ ustrojstvu, soderzhaniyu i organizacii rezhima raboty v doshkol'nyh organizaciyah [Sanitary and epidemiological requirements for the arrangement, content, and organization of work pattern in preschool organizations].

14. Tekhnicheskij reglament o trebovaniyah pozharnoj bezopasnosti [Technical regulations on fire safety requirements (as amended on December 27, 2018)].

15. GOST 31251-2008 Steny naruzhnye s vneshnej storony. Metod ispytanij na pozharnuyu opasnost'. [External walls from the outside. Fire hazard test method].

16. GOST 9573-96 Plity iz mineral'noj vaty na sinteticheskom svyazuyushchem teploizolyacionnye. Tekhnicheskie usloviya [Thermal insulation slabs made of mineral wool on a synthetic binder]. Dokipedia: 9573-96 Thermal insulation slabs made of mineral wool on a synthetic binder. Specifications.

17. GOST 22950-95. Plity mineralovatnye povyshennoj zhestkosti na sinteticheskom svyazuyushchem. Tekhnicheskie usloviya [Rigid mineral wool slabs on a synthetic binder. Specifications].

18. GOST 30244-94. Materialy stroitel'nye. Metody ispytanij na goryuchest'. [Construction materials. Combustibility test methods].

19. GOST 30402-96. Materialy stroitel'nye. Metod ispytaniya na vosplamenyaemost' [Construction materials. Flammability test method]. 